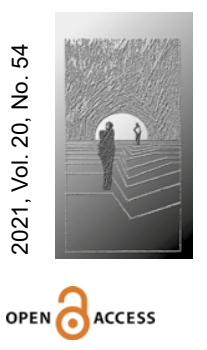

http://orcid.org/0000-0001-6922-6794 Akademia Ekonomiczno-Humanistyczna w Warszawie j.stadniczenko@interia.pl DOI: $10.35765 / h w .2061$

\title{
Rola rodziny w procesie rozwoju człowieczeństwa (wybrane zagadnienia)
}

\section{STRESZCZENIE}

CEL NAUKOWY: Celem opracowania jest analiza szczególnej roli rodziny w rozwoju dziecka, jego człowieczeństwa i potrzeb jego rozwoju, uwzględniając prawa człowieka w tym dziecka oraz teorie i filozofie prawa.

PROBLEM I METODY BADAWCZE: Problemem badawczym jest swoista rola rodziny w procesie rozwoju człowieczeństwa. W zakresie przyjętej metodologii zastosowano założenia filozofii personalistycznej, filozofii dialogu, praw człowieka i filozofii odpowiedzialności, a także analizę i krytykę literatury.

PROCES WYWODU: Opracowanie zwraca uwagę na trudności pojawiające się w prawidłowym wychowaniu dzieci w związku z rozwijającymi się mediami, brakiem odpowiedzialności i dojrzałości do pełnienia ról rodzicielskich.

WYNIKI ANALIZY NAUKOWEJ: Podjęte badania wskazują na konieczność podnoszenia wiedzy i umiejętności rodzicielskich zarówno u rodziców, jak i u osób zamierzających zostać rodzicami z poszanowaniem podmiotowości i godności osobowej dziecka.

WNIOSKI, INNOWACJE, REKOMENDACJE: Proponuje się edukowanie rodziców oraz przyszłych rodziców w zakresie prawidłowych postaw rodzicielskich, budowania relacji osobowej z dzieckiem w celu kształtowania w nim człowieczeństwa.

$\rightarrow$ SŁOWA KLUCZE: WYCHOWANIE DZIECI, RELACJA DZIECKA I RODZICA, ODPOWIEDZIALNOŚĆ RODZICIELSKA

\section{ABSTRACT}

The Role of the Family in the Process of Human Development (Selected Issues)

RESEARCH OBJECTIVE: The aim of the study is to analyze the special role of the family in the development of a child, its humanity and its development needs, taking into account human rights, including the child's rights, as well as theories and philosophies of law. 


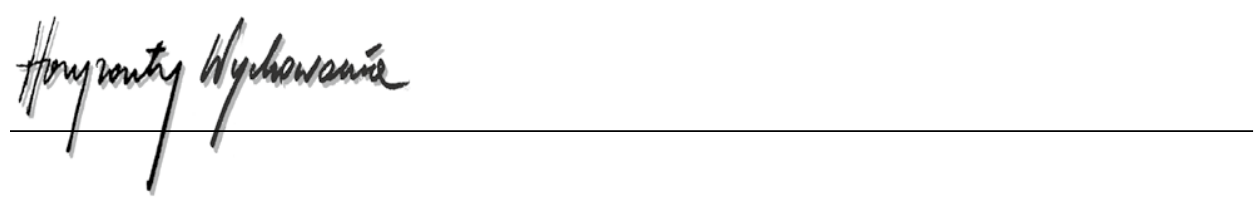

THE RESEARCH PROBLEM AND METHODS: The research problem is a special role in the process of human development. In terms of the adopted methodology, the assumptions of the personalistic philosophy, the philosophy of dialogue, human rights and the philosophy of responsibility, as well as analysis and criticism of the literature were used.

THE PROCESS OF ARGUMENTATION: The study draws attention to the difficulties appearing in the proper upbringing of children that arise in connection with the developing media, the lack of responsibility and maturity to fulfill the parental roles.

RESEARCH RESULTS: The research undertaken indicates the need to improve parental knowledge, competences and skills, both in parents and in those who intend to become parents, with respect for the subjectivity and personal dignity of the child.

CONCLUSIONS, INNOVATIONS, AND RECOMMENDATIONS: It is proposed to educate parents and future parents in the field of correct parental attitudes, building a personal relationship with the child in order to shape its humanity.

\section{$\rightarrow$ KEYWORDS: RAISING CHILDREN, RELATIONSHIP BETWEEN A CHILD AND A PARENT, PARENTAL RESPONSIBILITY}

Rodzina jest sobą, jeżeli buduje się na takich odniesieniach, na wzajemnym zaufaniu, na zawierzeniu wzajemnym. Tylko na takim fundamencie można też budować proces wychowania, który stanowi podstawowy cel rodziny $\mathrm{i}$ jej pierwszorzędne zadanie

(Jan Paweł II, 2008, s. 254)

\section{Wstęp}

Artykuł dotyczy instytucji społecznej, jaką jest rodzina, jej szczególnej roli w rozwoju dziecka i jego wychowania, rozumianych na bazie podstawowych praw człowieka, w tym praw dziecka i rodziny oraz filozofii dialogu, filozofii odpowiedzialności oraz filozofii personalistycznej.

W rodzinie - środowisku wychowawczym - kształtowane są podstawowe cechy osobowości człowieka. Wychowanie powinno obejmować wszystkie sfery rozwoju dziecka: fizyczną, umysłową, emocjonalną i duchową w równym stopniu, a nie tylko jedną, z czym obecnie często się spotykamy. W rodzinie nierozumiejącej potrzeb dziecka zostaje zaburzony jego rozwój, który powinni wspomagać najpierw rodzice, opiekunowie, później nauczyciele. Rodzina w swej trosce o harmonijny rozwój dziecka ma prawo uzyskać stosowne wsparcie instytucji, ale bez przejmowania odpowiedzialności rodzicielskiej.

Podjęta problematyka wskazuje na potrzebę interdyscyplinarnego podejścia do rodziny i wychowania oraz uświadomienie, jak istotne jest uznanie znaczenia prawidłowego wychowania dziecka w rodzinie przez dojrzałych i odpowiedzialnych rodziców. 
Współcześnie rodzina jako główne środowisko wychowawcze wydaje się zanikać. Obecnie można zauważyć, że to środki masowego przekazu, seriale, gwiazdy mają większy wpływ na wychowanie dzieci niż rodzice (Kornas-Biela, 2001).

Jak wynika z obserwacji rodzin w ciągu 15 lat praktyki adwokackiej autorki, obecnie rodzicom często brak odpowiedzialności rodzicielskiej i dojrzałości do pełnienia ról rodzicielskich, co przekłada się na wiele spraw sądowych dotyczących ingerencji sądów we władzę rodzicielską. Wiele spraw sądowych (rozwody, separacje, burzliwe spory o alimenty itp.) wynika z nieprawidłowej komunikacji interpersonalnej, nieprawidłowych relacji między małżonkami.

Niewątpliwie w naszym kręgu kulturowym rodzina jest najważniejszym środowiskiem wychowawczym dla każdego człowieka. W niej powinniśmy nauczyć się podstawowych wartości oraz jak kochać, przebaczać, żyć w jedności i zgodzie oraz znajdować sens życia.

\section{Wybrane uwarunkowania rozwoju dziecka w rodzinie}

Rodzina pełni liczne społeczne funkcje i od niej rozpoczyna się cały skomplikowany proces przekazywania, przyswajania kultury oraz wartości społecznych i indywidualnych. Rodzina jest systemem modelowych zachowań społecznych, jest nauczycielem ról rodzinnych i pozarodzinnych, jest szkołą społecznych postaw. Rodzina przesądza i decyduje o jakości całych społeczeństw. Prawidłowe funkcjonowanie społeczeństwa jest ściśle zdeterminowane prawidłowym funkcjonowaniem rodzin (Podgórski, 2008, s. 126) Prawidłowo funkcjonująca rodzina pozwala trwać wartościom uniwersalnym i najważniejszym, przez co zachowuje spójność systemów nie tylko wartości, ale przede wszystkim systemów społecznych.

Wychowanie jest istotnym zadaniem każdego społeczeństwa, ponieważ jest czynnikiem postępu społecznego i dlatego konsekwencją tego jest powszechne zainteresowanie procesem wychowawczym w dziedzinie wielu nauk (pedagogiki, psychologii, socjologii czy prawa).

Należy podkreślić, że wychowanie jest niezbywalnym prawem i obowiązkiem rodziców, a dopiero potem wspólnoty społecznej. Wychowanie, w którym nie wprowadza się dzieci i młodzieży w świat wartości, jest z reguły wychowaniem połowicznym i mało skutecznym, a nierzadko bezmyślnym i społecznie szkodliwym. Przede wszystkim nie przygotowuje ono wystarczająco do podjęcia ważnych życiowych decyzji, zgodnych z podstawowymi zasadami moralności. Wartości są filarami, na których opiera się życie społeczne, osobiste i wspólnotowe (Łobocki, 2003, s. 102-103).

Kryzys wartości, a w zasadzie nieumiejętność ich rozumienia, którego jesteśmy świadkami i w pewnym stopniu uczestnikami, nie mógł ominąć takich instytucji społecznych, jak rodzina, szkoła czy Kościół, a więc nie pominął autorytetu rodzica, nauczyciela, szkoły i Kościoła. Nie ulega wątpliwości, że liczne zjawiska, ale też atrybuty współczesnej cywilizacji, środki masowego przekazu, takie jak np. internet, telewizja, radio, 


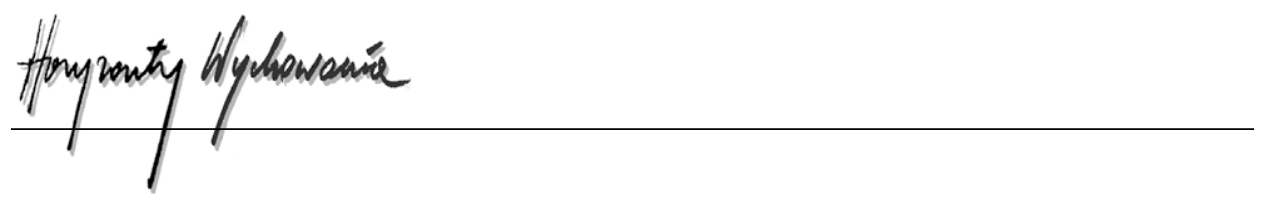

coraz szybsze poznawanie świata przez dzieci i młodzież, większe swobody obyczajowe, rozluźnienie moralne, oddziaływanie na młode pokolenie oraz wiele innych środowiskowych, czyli pozadomowych czynników nie sprzyjają kultywowaniu tradycyjnego autorytetu rodzicielskiego.

Jak słusznie zauważa E.V. Sullivan, mass media stały się najpotężniejszym instrumentem kształtowania systemu wartości. Życie zaczyna nabierać charakteru telewizyjnego. Obecnie popularne jest również kreowanie własnego Ja i komunikowanie się z innymi poprzez portale społecznościowe i blogi. Doświadczenie zdobyte poprzez kontakt z mediami w coraz większym stopniu zastępuje rzeczywiste doświadczenia. Nie ma znaczenia, czy coś jest prawdziwe, czy fałszywe - jeśli zdarza się w mass mediach, jest po prostu wiarygodne. Utracona została zdolność do rozróżniania kształtu i jego cienia (Melosik, 2007, s. 76-77).

Warto zauważyć, że współczesne społeczeństwa charakteryzują się ciągłym zrywaniem i budowaniem nowych więzi przez ludzi funkcjonujących w ramach sieci. Zauważyli to socjolodzy rodziny, którzy starają się dostosować do tego modelu życia społecznego definicje „podstawowej komórki społecznej”. Normy społeczne, np. religijne, obyczajowe, moralne, nie zapewniają trwałości rodziny, nie stabilizują jej tradycyjnej formy. Pojawiają się obecnie liczne formy alternatywne wobec klasycznej rodziny nuklearnej. W nawiązaniu do nich tworzone są różne teorie w ramach nauk społecznych. Jak zauważa Tomasz Szlendak, „spotykamy najczęściej takie oto formy - homorodziny, samotni rodzice, trwali kohabitanci, rodziny wizytowe i rodziny migrantów oraz grona przyjacielskie, rodzinne patchworki (rodziny rekonstruowane po rozwodach)" (Szlendak, 2015, s. 217). Zdaniem socjologów nie mamy do czynienia z kryzysem, ale ze zmianami związanymi z przeobrażeniami ekonomicznymi, społecznymi, kulturowymi, filozofią życia, procesem indywidualizacji oraz źle pojmowaną wolnością.

Prawidłowo przebiegający proces rozwoju człowieczeństwa u dziecka dokonuje się przede wszystkim w rodzinie i wymaga zaspokojenia jego podstawowych potrzeb, na bazie których będzie mogła się rozwijać dojrzała emocjonalność człowieka warunkująca działania prospołeczne. Wymaga również prawidłowych postaw rodziców, dzięki którym dziecko kształtuje realny obraz siebie, wiarę we własne siły, poczucie godności, samodzielność, pragnienie twórczości. Szczególnie istotne staje się zaspokojenie potrzeby miłości i przynależności, bezpieczeństwa, zrozumienia i szacunku. Już w pierwszych chwilach życia, w okresie prenatalnym, dziecku towarzyszą uczucia. Z wielu badań wynika, że już w okresie prenatalnym dziecko potrzebuje życzliwości i miłości rodziców. Stały bliski kontakt z dzieckiem leży u podstaw kształtowania się prawidłowej więzi emocjonalnej. W atmosferze akceptacji, życzliwości wyrasta człowiek, który potrafi odkrywać własną wartość, zaakceptować siebie i innych.

Zaspokojenie podstawowych potrzeb człowieka pozwala na kształtowanie się potrzeb wyższych, które prowadzą ku pełni człowieczeństwa. Dzięki nim człowiek odczuwa tęsknotę za pięknem, doskonałością, prawdą, za ofiarną miłością i odpowiedzialnością. Natomiast prawidłowe postawy rodzicielskie, tzn. akceptacja dziecka, czyli przyjęcie go takim, jakim ono jest, współdziałanie z dzieckiem, zaangażowanie w jego sprawy, 
dawanie dziecku rozumnej swobody, dostosowanej do wieku, uznawanie praw dziecka jako pełnoprawnego członka rodziny przyczynia się do prawidłowego rozwoju jego ufności, życzliwości, chęci współdziałania, odpowiedzialności, do wiary we własne siły (Ziemska, 1977). Zauważenia wymaga również złożoność relacji między członkami rodziny, którzy tworzą sytuacje wychowawcze i wyposażają w „podstawowe sensy istotowe dla dalszego życia w społeczeństwie poza wspólnotą rodzinną (...). Dziecko znajduje się zawsze w koniecznej relacji do rodziny, jeśli nie naturalnej, to zastępczej. Konieczność ta wpisana jest w naturę i obiektywny układ inklinacji i struktur" (Stadniczeńko, 2019, s. 39-40).

\section{Odpowiedzialność rodziców w kształtowaniu człowieczeństwa}

Wybór roli rodzica jest decyzją moralną i powinien być wolny, świadomy, racjonalny, odpowiedzialny oraz nastawiony na urzeczywistnianie wartości etycznych. Człowiek podejmując rolę rodzica, musi stać się odpowiedziany już nie tylko za siebie, ale również za dziecko.

Odpowiedzialność obliguje człowieka mądrego, którym powinien być rodzic, do myślenia według wartości moralnych i do działań nastawionych na ich urzeczywistnianie. Gotowość do ponoszenia i podejmowania odpowiedzialności stanowi, jeśli nie najważniejszą, to na pewno bardzo ważną cnotę człowieka mądrego. Kolejnym jego wyróżnikiem jest umiejętność trafnego wyboru moralnego, warunkowana zasobem wiedzy etycznej i empirycznej. Rezultatem powinno być opracowanie możliwie najlepszego sposobu postępowania w danej sytuacji, służącego realizacji wybranych wartości.

Jak pisze Hans Jonas:

Pierwszym i najogólniejszym warunkiem odpowiedzialności jest moc sprawcza, a więc to, że działanie ma wpływ na świat; drugim, że działanie takie podlega kontroli jego sprawcy; trzecim zaś, że do pewnego stopnia może on przewidzieć jego skutki. Jeśli te warunki konieczne są spełnione, możliwa jest „odpowiedzialność”, ale w dwu dalece odmiennych sensach: a) odpowiedzialność jako bycie rozliczanym „za” swoje czyny, jakie by były; oraz b) odpowiedzialność „za” określone przedmioty, która angażuje sprawcę do określonych czynów względem przedmiotów. (Proszę zauważyć odmienny zakres owego „za”!). Pierwsza odpowiedzialność jest pojęciem formalnym, druga treściowym; więc gdy mówimy, że ktoś jest odpowiedziany za to, co się wydarzyło (bez intencji chwalenia czy potępienia), oraz że ktoś jest osobą odpowiedzianą, tzn. respektuje swe obowiązki (co jest pochwałą) to naprawdę mówimy o dwu różnych sprawach (Jonas, 1996, s. 169).

Dalej Hans Jonas pisze:

(...) odpowiedzialność jest przede wszystkim odpowiedzialnością ludzi za ludzi i to jest archetyp wszelkiej odpowiedzialności. To pokrewieństwo podmiotu i przedmiotu w stosunku do odpowiedzialności zakłada, że choć stosunek sam w sobie i w każdym poszczególnym przypadku jest jednostronny, to jednak $z$ istoty jest odwracalny i zawiera możliwą 


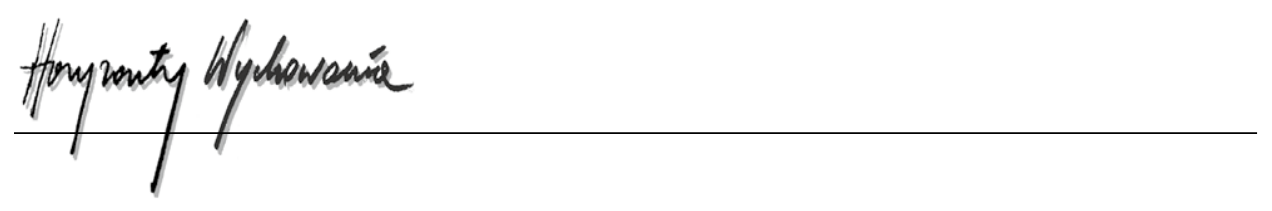

wzajemność. Istotnie pod względem rodzaju wzajemność istnieje zawsze, o ile ja, który jestem odpowiedziany za kogoś, przez to, że żyję wśród ludzi, jestem także przedmiotem odpowiedzialności kogoś innego. Wynika to z nieautarkiczności człowieka; i tak czy inaczej każdy wpierw doświadczył na sobie co najmniej podstawowej odpowiedzialności cechującej rodzicielską troskę (Jonas, 1996, s. 181).

Hans Jonas podkreśla (1996, s. 232 i n.), że relacja rodzic - dziecko jest ponadczasowym archetypem wszelkiej odpowiedzialności. Jest to archetyp pod względem genetycznym i typologicznym, lecz również - z powodu jego bezpośredniej oczywistości - epistemologicznym.

Odpowiedzialność oznacza możność i gotowości człowieka do ponoszenia konsekwencji za skutki swojego postępowania. Roman Ingarden wyróżnia odpowiedzialność biernie ponoszoną i aktywnie podejmowaną (Ingarden, 1975, s. 77). Wyróżniamy również odpowiedzialność formalną, w której miarą odpowiedzialności człowieka jest jego stosunek do właściwych mu obowiązków i reguł postępowania (Szawarski, 1987, s. 24) oraz substytucyjną - jest to odpowiedzialność podejmowana i ponoszona za drugiego człowieka. Dla współczesnego myśliciela francuskiego Emmanuela Lévinasa „Drugi” to „Twarz”, która prosi mnie i nakazuje mi „Nie zabijaj” (Lévinas, 2000, s. 54). Drugi człowiek - mój bliźni, za którego jestem odpowiedzialny - to ktoś, kto apeluje do mnie o zachowanie swego istnienia. W relacji odpowiedzialności pomiędzy mną a drugim - pomiędzy „Ja” i „Ty” - „Ja” jest członem silniejszym tej relacji; Drugi natomiast jest jej elementem słabszym, wymagającym troski, zagrożonym w swoim istnieniu (Lévinas, 2000, s. 106).

Odpowiedzialność znajduje się u podstaw etycznego działania człowieka, szanując autonomię podmiotu, wskazuje na podstawowe odniesienia, jakimi są odpowiedzialność za własne działanie i odpowiedzialność za świat, co jest szczególnie widoczne w dobie globalizacji. Emmanuel Lévinas w tym kontekście zauważa, że „odpowiedzialność jest tym, co ciąży na mnie i czego jako człowiek nie mogę odrzucić. Ten ciężar jest najwyższą godnością człowieka" (Lévinas, 1998, 101).

By odpowiedzialność zrozumieć, trzeba wykroczyć poza jej prawną czy moralną wykładnię. Współczesnego znaczenia pojęcia odpowiedzialności nie można też trafnie uchwycić i oszacować, nie zagłębiając się w jego filozoficzne źródła.

Odpowiedzialność rodzicielska to pewnego rodzaju zadanie, postawa oraz relacje rodziców z dzieckiem, wykonywane z poszanowaniem jego godności i praw, zgodnie z porządkiem społeczno-prawnym. Ma ona na celu troskę o dziecko i zaspokajanie jego potrzeb, przygotowanie do życia w rodzinie i społeczeństwie. Jest realizowana w szczególności przez wykonywanie obowiązków i praw w zakresie pieczy nad osobą i majątkiem dziecka, reprezentacji, utrzymywania relacji osobistych, ustalania pochodzenia dziecka, jego imienia i nazwiska, miejsca pobytu. Odnosi się odpowiednio do osób, które na mocy orzeczenia sądu ponoszą wobec dziecka taką odpowiedzialność jak rodzice. Z odpowiedzialnością wiążą się: powinność rodziców, dialog, wolność, sprawiedliwość, godność osobowa, prawda, troska, wzajemny szacunek i pomoc.

Odpowiedzialność nawiązuje do istnienia wartości i zachodzących między nimi związków, które są pierwszym warunkiem idei odpowiedzialności. W odpowiedzialności 
rodzicielskiej występuje kilka aspektów odpowiedzialności: moralny, psychologiczny, pedagogiczny, społeczny i prawny. Odpowiedzialność ma wymiar podmiotowy „za kogoś”, „za coś”, „przed kimś za coś” i „przed samym sobą za coś”.

Człowieczeństwo immamentnie łączy się z odpowiedzialnością każdego człowieka, zwłaszcza rodzica, wyraża się między innymi w określonych postawach rodzicielskich. Prawidłowe postawy rodzicielskie wymagają umiejętności emocjonalnego zaangażowania się w sprawy drugich oraz autentyczności i otwartości w relacjach z innymi. Jest to umiejętność unikania w kontaktach z dziećmi fałszu, zakłamania, pozorów i konwencji. Tylko w rodzinach o prawidłowych postawach wychowawczych, w atmosferze pełnej rozumnej miłości mogą wychowywać się dzieci radosne, kochające, mające poczucie własnej wartości i godności, a także życzliwe i otwarte na potrzeby innych. Rodzice stają się dla dziecka wzorem, z którym dziecko szczególnie silnie się utożsamia. Zjawisko to prowadzi do przyjmowania przez dziecko postaw, poglądów i ideałów rodziców. Identyfikacja z rodzicami sprzyja większemu opanowaniu, zrównoważeniu w sferze osobowości, wytwarzaniu się pozytywnych postaw wobec otoczenia. Tylko w zgodnej, harmonijnie funkcjonującej rodzinie realizują się w pełni role ojca, matki i dzieci. W rodzinie zachodzi proces identyfikacji dziecka z własną płcią będący istotnym czynnikiem leżącym u podstaw rozwoju człowieczeństwa.

W procesie rozwoju człowieka jedną z podstawowych ról odgrywa również spójność układu normatywnego. Normy będą pełniły funkcję regulującą ludzkie działania, jeżeli zostaną odpowiednio przyswojone. Najprostszy sposób przyswajania normy polega na jej werbalnym opanowaniu. Taki sposób poznania norm nie pociąga za sobą konsekwencji podporządkowania się im. Aby normy mogły stać się wymaganiami wewnętrznymi, muszą zostać zinternalizowane, tzn. musi nastąpić przekształcenie nakazu zewnętrznego we własny (Gołąb, 1979). Normy przyjmują rolę regulacyjną w działaniu ludzkim wtedy, gdy dana osoba zaczyna odczuwać poczucie powinności działania w określony sposób mimo braku kontroli zewnętrznej, poczucie dumy ze spełnionego obowiązku w przypadku jej zrealizowania lub niepokoju, gdy ktoś inny, szczególnie bliski, narusza normy, mimo że jego czyn nie dotyka w żaden sposób interesów jednostki (Reykowski, 1979).

\section{Jak słusznie zauważa Elżbieta Sujak,}

(...) wychowanie jest propozycją pewnej hierarchii wartości, zbioru zasad postępowania i niczym innym jak propozycją. Bolesne pytanie nurtujące rodziców, czy te najbardziej ukochane prawdy i wartości życia zostaną przez dziecko przyjęte za własne, pokochane i strzeżone - łatwiej znajdą uspokajającą odpowiedź w oczach dziecka i młodego człowieka, gdy całe dzieciństwo, cały dramat rozwoju i przyjmowania opieki i wychowania będzie rozgrywać się w atmosferze utrzymanego, zawsze żywego kontaktu uczuciowego (Sujak, 1983, s. 176).

Autorka ta zaznacza w innej książce, że istnieje powszechne przekonanie, iż dom rodzinny stanowi dla człowieka miejsce bezpieczne, spokojne, w którym najswobodniej można być sobą, a najbliżsi są praktycznie zobowiązani przyjmować dziecko zawsze 


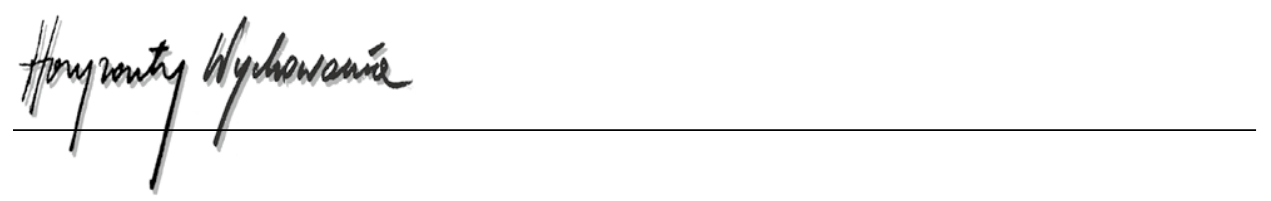

takim, jakie jest. W domu pragniemy odnajdywać pocieszenie, zrozumienie i oparcie. Trafnie zauważa również

(...) jeżeli rzeczywistość życia i rodziny okazuje się inna, gdy w domu wytwarzają się napięcia, żale, pretensje, czujemy się skrzywdzeni, zawiedzeni, pozbawieni czegoś, co nam się należy. Czasem wtedy rodzi się pokusa, by opuścić ten dom... Wtedy pojawiają się nieuniknione trudności, które nie przekreślając jego wartości, wstawiają wymagania dostosowania się i rozwiązywania kolejno pojawiających się kryzysów i konfliktów (Sujak, 1978, s. 463).

\section{Podsumowanie}

Na kształtowanie się osobowości dziecka mają wpływ najpierw rodzice, przy czym dominuje on zazwyczaj przez wiele lat. Wpływ ten jest rozległy i oddziałuje na rozwój funkcji poznawczych dziecka, a później na jego osiągnięcia szkolne, kształtowanie się równowagi uczuciowej i dojrzałości społecznej, formowanie obrazu samego siebie i stosunek do siebie oraz do grupy rówieśniczej, a także na późniejsze realizowanie ról rodzinnych (Ziemska, 2009, s. 6).

Odpowiedzialność rodzicielska ma swój cel, którym jest ukształtowanie człowieczeństwa u dziecka, i kończy się wraz z uzyskaniem przez dziecko dojrzałości.

W rodzinie, w której postawa rodziców otwarta jest na dialog, dziecko ma szansę na prawidłowy rozwój. Bycie z dzieckiem od najmłodszych lat, wchodzenie z nim w dialog uczy prawidłowych relacji z innymi, przyjęcia postawy otwartości i miłości do rodziców oraz aby mogło ono w przyszłości budować swoje relacje z ludźmi oparte na dialogu. Stąd konieczność szerokiej edukacji rodziców, przygotowania ich do prowadzenia dialogu wychowawczego we współpracy z innymi środowiskami odpowiedzialnymi za wychowanie.

Na szczególne znaczenie wkładu Emmanuela Lévinasa do pedagogicznej i prawniczej dyskusji o wolności i odpowiedzialności zwraca uwagę Stanisław Stadniczeńko w książce pt. Pedagogika prawa, podkreślając, że człowiek został powołany do bycia odpowiedzialnym za drugiego i traktowania go jako wyłącznie drugiego podmiotu, wskazując jednocześnie, że na każdym etapie funkcjonowania normy prawnej osoby poczuwające się do prawdziwej (a nie tylko formalnej) odpowiedzialności za system prawny, dobro wspólne i życie społeczne nie powinny tracić z oczu istoty człowieczeństwa i najgłębszego sensu ludzkiego życia (Stadniczeńko i Zamelski, 2020, s. 110 i n.).

Wykorzystanie wiedzy i umiejętności w rozwoju dziecka powinno ułatwić podjęcie rozmowy z dzieckiem, uczenie go rozmowy, by na zasadach dialogu budować wzajemne relacje, pokonywać pojawiające się trudności i wspólnie dążyć do wytyczonych celów w rozwoju człowieczeństwa. Prowadzenie dialogu jest rzeczywistością zakorzenioną w naturze ludzkiej, a egzystencja ludzka ma charakter dialogiczny. 


\section{BIBLIOGRAFIA}

Gołąb, A. (1979). Normy moralne, a gotowość do udzielenia pomocy innym. W: J. Reykowski (red.), Osobowość a społeczne zachowania ludzi (s. 56-78). Warszawa: Książka i Wiedza.

Ingarden, R. (1975). O odpowiedzialności i jej podstawach ontycznych. W: R. Ingarden, Książeczka o człowieku (s. 72-89). Kraków: Wydawnictwo Literackie.

Jan Paweł II (2008). Homilie i przemówienia z pielgrzymek - Europa. Cz. 1: Polska. Kraków: Wydawnictwo $\mathrm{M}$.

Jonas, H. (1996). Zasada odpowiedzialności. Etyka dla cywilizacji technologicznej (M. Klimowicz, tłum). Kraków: Wydawnictwo Platan.

Kornas-Biela, D. (2001). Rodzina: źródło życia i szkoła miłości. Lublin: TN KUL.

Lévinas , E. (1998). Etyka i nieskończony. Rozmowy z Philippem Nemo (B. Opolska-Kokoszka, tłum). Kraków: Wydawnictwo Naukowe PAT.

Lévinas, E. (2000). Imiona własne (J. Margański, tłum.). Warszawa: Wydawnictwo KR.

Łobocki, M. (2003). Teoria wychowania w zarysie. Kraków: „Impuls”.

Melosik, Z. (2007). Kultura popularna jako czynnik socjalizacji. W: Z. Kwieciński i B. Śliwerski (red.), Pedagogika, (t. 2, s. 76-77). Warszawa: Wydawnictwo Naukowe PWN.

Podgórski, R. (2008). Socjologia mikrostruktury. Podręcznik akademicki. Olsztyn-Bydgoszcz: Oficyna Wydawnicza Branta.

Reykowski, J. (1979). Motywacja. Postawy prospołeczne a osobowość. Warszawa: Państwowe Wydawnictwo Naukowe.

Stadniczeńko, S.L. (2019). Podstawy aksjologiczne i intelektualne kształtowania projektu Kodeksu rodzinnego. W: S.L. Stadniczeńko i M. Michalak (red.), O potrzebie nowego Kodeksu rodzinnego i jego podstawach aksjologicznych. W 30. rocznicę uchwalenia Konwencji o prawach dziecka (s. 53-82). Toruń: Wydawnictwo Adam Marszałek.

Stadniczeńko, S.L. i Zamelski, P. (2020). Pedagogika prawa. Pomoc w zrozumieniu prawa i sensu życia. Warszawa: Wydawnictwo AEH.

Sujak, E. (1978). Sytuacje konfliktowe w małżeństwie i rodzinie. W: F. Adamski (red.), Miłość, małżeństwo, rodzina (s. 47-56). Kraków: Wydawnictwo Apostolstwa Modlitwy.

Sujak, E. (1983). Kontakt psychiczny w małżeństwie i rodzinie. Wrocław: Wydawnictwo Wrocławskiej Księgarni Archidiecezjalnej.

Szawarski, Z. (1987). Rozmowy o etyce. Warszawa: Wydawnictwa Szkolne i Pedagogiczne.

Szlendak, T. (2015). Socjologia rodziny. Ewolucja, historia, zróżnicowanie. Warszawa: Wydawnictwo Naukowe PWN.

Ziemska, M. (1977). Rodzina a osobowość. Warszawa: Wiedza Powszechna.

Ziemska, M. (2009). Postawy rodzicielskie. Warszawa: Wiedza Powszechna.

\section{Copyright and License}

This article is published under the terms of the Creative Commons Attribution - NoDerivs (CC BY- ND 4.0) License http://creativecommons.org/licenses/by-nd/4.0/ 